\title{
BANDING POLYMORPHISM IN \\ TRACHIA VITTATA
}

\section{N.A. Madhyastha ${ }^{1}$, G.M. Rajendra and Sandhya Shanbhag}

Malacology Centre, Poornaprajna College, Udupi 576101, India E-mail: ${ }^{1}$ n_a_madhyastha@yahoo.com

web supplement

Land snails show considerable variations in respect to their shell banding pattern which has been studied for a number of species (Rex, 1972; Roth, 1981; Roth \& Bogan, 1984; Hazel \& Johson, 1990; Davison, 2001). The genetic basis for such pattern has been worked out in detail for Cepaea memoralis (Cain \& Curry, 1963). Polymorphism as a means of survival during natural selection through isolating mechanisms over long periods of time has also been attributed (Goldberg \& Sevens 1998). Super gene influence and habitat preference must have evolved in different species of land snails (Hazel \& Johnson, 1990). Such studies are not available for banding pattern of any land snail species found in India.

About twenty aestivating Trachia vittata were collected during September and December 2002 from the campus of M.S. University, Thirunelveli, Tamil Nadu, India. The snails were hand picked carefully, after recording the microhabitat for each specimen collected. The banding pattern on the shells were observed with the help of a hand lens and grouped in to $u$ (umbilical), $m$ (middle), and $s$ (sutural) depending upon the

location. The thickness and length of each band on every shell was also recorded and analyzed in relation to microhabitat (Table $1)$.

The shells of Trachia vittata are whitish with varying degree of brown bands. The banding pattern shows variation both in number ( 0 to 9$)$ and thickness (Image $\left.1^{\mathrm{w}}\right)$. The band width varies from very thin $(\mathrm{c} 0.1 \mathrm{~mm})$ to broad $(>2 \mathrm{~mm})$. The bands are broadest at the base, near the margin of the mouth of the shell gradually tapering at the tip. A few snails which were found exposed to bright sunlight were paler in colour and is suggestive of an adaptive variation as in the case of Theba pisana (Cowie, 1985; Hazel \& Johnson, 1990). However, the number of bands and the thickness of each band seem to have no relation to the microhabitat (Table 1). This is in contrast to the studies on Theba pisana where unbanded and fully banded snails have a significant role in microhabitat choice. The genetically controlled banding patterns of the shell, play a relative role of chance in the evolution of land snail (Cain, 1984). The intra population variability of land snail shells is influenced by natural selection (Goldberg \& Steven, 1998). The adaptive role of this pattern in $T$. vittata, to avoid predation by birds, is less likely, as they were all found in equal proportion and were found at about the same height and microhabitat with a canopy cover of $15-20 \%$. Furthermore, the variation of banding pattern in $T$ vittata is irrespective of orientation, the plant height and canopy cover. Hence, there is need to probe further into the adaptive significance of this unique pattern, in Trachia vittata.

\section{REFERENCES}

Cain, A.J. and J.D. Currey (1963). Area effects in Cepaea. Philosophical Transactions of the Royal Society Series B 246: 1-81.

Table 1. Showing the banding pattern in Trachia vittata in relation to different parameters.

\begin{tabular}{|c|c|c|c|c|c|c|}
\hline & $\begin{array}{l}\text { Type of banding (u - umbilicus, } \mathrm{m} \text { - middle, } \\
\mathrm{s} \text { - sutural) }\end{array}$ & $\begin{array}{l}\text { Part on which } \\
\text { snail found }\end{array}$ & $\begin{array}{l}\text { Height on } \\
\text { which snail } \\
\text { found }(\mathrm{m})\end{array}$ & $\begin{array}{l}\text { Height of } \\
\text { plant in } \\
\text { meters }\end{array}$ & $\begin{array}{l}\text { Canopy } \\
\text { cover } \\
\text { in } \%\end{array}$ & Orientation \\
\hline 1 & $\mathrm{u}-3$ close thick, $\mathrm{m}-3$ thin 1 broad, $\mathrm{s}-2$ moderate & Bark & 1.07 & 3.04 & 15 & W \\
\hline 2 & u-close bands & $\begin{array}{l}\text { creeper stem } \\
\text { modification }\end{array}$ & 0.91 & 1.83 & 15 & W \\
\hline 3 & u-2 thin, 2 broad, s-2 moderate & Bark & 1.37 & 1.83 & 10 & $E$ \\
\hline 4 & $\mathrm{u}-1$ thin, $\mathrm{m}-3$ moderate, 1 broad, $\mathrm{s}-1$ thin & Bark & 1.23 & 1.83 & 10 & $\bar{W}$ \\
\hline 5 & $\mathrm{u}-1$ thin, $\mathrm{m}-3$ moderate, 1 broad, $\mathrm{s}-2$ thin & Bark & 1.52 & 1.83 & 10 & W \\
\hline 6 & $\mathrm{u}-1$ thin, 2 moderate, $\mathrm{s}-1$ moderate, & Bark & 1.52 & 3.04 & 15 & W \\
\hline 7 & $\mathrm{u}-2$ thin, $\mathrm{m}-1$ broad & Bark & 1.83 & 6.1 & 25 & $E$ \\
\hline 8 & $\mathrm{u}-1$ thin, $\mathrm{m}-3$ moderate & Bark & 1.52 & 2.44 & 20 & $\bar{S}$ \\
\hline 9 & $\mathrm{u}-2$ thin, $\mathrm{m}-1$ moderate, s-thin, 1 broad & Bark & 0.91 & 2.44 & 20 & $\mathrm{E}$ \\
\hline 10 & $\begin{array}{l}\mathrm{u}-1 \text { thin, } \mathrm{m}-1 \text { moderate, } 1 \text { narrow, } \mathrm{s}-1 \text { moderat, } \\
1 \text { narrow, } 1 \text { broad }\end{array}$ & Bark & 0.31 & 2.44 & 20 & $\mathrm{~S}$ \\
\hline 11 & $\mathrm{u}-4$ thin, $\mathrm{m}-1$ broad, 1 moderate, s- 1 thin, 1 broad & Bark & 1.23 & 2.74 & 15 & W \\
\hline 12 & $\begin{array}{l}\text { u-3 thin, } 2 \text { moderate, } 1 \text { broad, } \mathrm{m}-2 \text { broad, } \\
\text { s-2narrow }\end{array}$ & Bark & 1.07 & 2.74 & 15 & W \\
\hline 13 & $\mathrm{u}-1$ thin, 2 moderate, $\mathrm{m}-1$ broad, $\mathrm{s}-2$ broad & Bark & 1.23 & 2.74 & 15 & W \\
\hline 14 & $\mathrm{u}-1$ thin, $\mathrm{m}-2$ broad, $\mathrm{s}-1$ broad & Bark & 1.52 & 2.74 & 15 & W \\
\hline 15 & u-1 moderate, 1 thin, $\mathrm{m}-1$ broad, s-1 broad & Bark & 1.83 & 2.74 & 15 & $E$ \\
\hline 16 & $\mathrm{~m}-2$ thin, $\mathrm{s}-1$ thin, 1 broad & Bark & 0.62 & 1.23 & 5 & $\mathrm{~N}$ \\
\hline 17 & $\mathrm{u}-1$ thin, $\mathrm{m}-2$ thin, 1 broad, $\mathrm{s}-1$ thin & Bark & 0.62 & 5.18 & 25 & W \\
\hline 18 & u-2 moderate, $\mathrm{m}-1$ broad, 1 thin, $\mathrm{s}-2$ thin & Bark & 1.52 & 3.04 & 15 & $\mathrm{~S}$ \\
\hline 19 & $\mathrm{u}-3$ thin, $\mathrm{m}-1$ moderate, 2 thin, $\mathrm{s}-2$ thin, 1 broad & Bark & 1.23 & 3.04 & 15 & $\mathrm{~S}$ \\
\hline 20 & u-2 broad, m-1 broad, s-1 broad, 1 thin & Bark & 1.83 & 3.04 & 15 & W \\
\hline 21 & u-nil, m-4 broad, s-1 broad & Bark & 1.83 & 2.44 & 15 & $\mathrm{~S}$ \\
\hline 22 & $\mathrm{u}-3$ thin, $\mathrm{m}-4$ thin, $\mathrm{s}-1$ broad & Bark & 1.52 & 2.13 & 10 & W \\
\hline 23 & u-4 moderate, $\mathrm{m}-2$ moderate, $\mathrm{s}-2$ broad & Bark & 0.31 & 2.13 & 10 & W \\
\hline 24 & $u-2$ thin, $m-4$ broad, $s-2$ thin & Bark & $3 \mathrm{~cm}$ & 2.13 & 10 & W \\
\hline 25 & Plain, bands faded. & Bark & 1.83 & 2.13 & 10 & $\mathrm{~s}$ \\
\hline
\end{tabular}

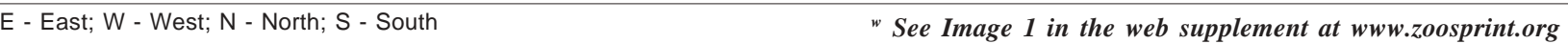


Cain, A.J., P.M. Sheppard and J.M.B. King (1968). Studies on Cepaea 1. The genetics of some morphs and varieties of Cepaea nemoralis (L.). Philosophical Transactions of the Royal Society Series B. 253-396.

Davison, A. (2001). Land snails as a model to understand the roles of history and selection in the origin of biodiversity, pp. 25-26. In: The $20^{\text {th }}$ Symposium of the Society of Population Ecology, Evolution and Biodiversity: Theory and Facts, Yamagata.

Goldberg, R.L. and M. Severns (1998). Isolation and evolution of the Amphidromus in Nusa tenggara, pp. 1-6. Conchologists of America. Hazel, W.N. and M.S. Johnson (1990). Microhabitat choice and polymorphism in the land snail Theba pisana (Muller). Heredity 65 : 449-454.

Rex, M.A. (1972). The relationship of island area and isolation to color polymorphism in Liguus fasciatus (Pulmonatea, Bulimulidae). Breviora 391: $15 \mathrm{pp}$

Roth, B. (1981). Shell color and banding variation in two coastal colonies of Monadenia fidelis (Grey) (Gastropoda: Pulmonata). Wasmann Journal of Biology 39-51.

Roth, B. and A.E. Bogan (1984). Shell colour and banding parameters of the Liguus fasciatus phenotype (Mollusca: Pulmonata). American Malacology Bulletin 3(1): 1-10.

\section{ACKNOWLEDGEMENT}

The authors are grateful to Ministry of Environment and Forests, Government of India, for financial support through a grant under AICOPTAX project. We also thank Chief Wildlife Warden, Government of Tamil Nadu, Chennai.

\section{Nan}

\section{VETBRIG}

\section{MANAGEMENT OF POSTERIOR PARESIS IN A LION (PANTHERA LEO)}

\section{Dilip Kumar Das ${ }^{1}$, G. Srinivas Murthy ${ }^{2}$ and Narayana Bhat ${ }^{3}$}

1 Veterinarian, Rescue Centre, Bannerghatta Biological Park, Bannerghatta Post, Bangalore, Karnataka 560083, India

${ }^{2}$ Assistant Director (Veterinary Services), Bannerghatta Biological Park, Bannerghatta Post, Bangalore, Karnataka 560083, India

${ }^{3}$ Associate Professor and Head, Department of Epidemiology \& Preventive Medicine, Veterinary College Hospital, Veterinary College, Hebbal, Bangalore, Karnataka 560024, Karnataka, India

Email: ${ }^{1}$ dilipdas_77@rediffmail.com; ${ }^{2}$ srinivas_murthy@vsnl.net

web supplement

Paresis or partial paralysis is loss of voluntary motor function. This could be due to dysfunction of neural or muscular systems (Oliver, 1987). Posterior paresis or pelvic limb paresis or paraparesis involves hind quarters mainly hind legs. A case report of posterior paresis and its management in a captive lioness is reported.

A lion aged about 10 years housed at the rescue centre, Bannerghatta Biological Park, Bangalore, was not able to bear weight on the hind legs (Image $1^{\mathrm{w}}$ ). It was a sudden onset and there was no history of any injury to the hind quarters or any infighting between the inmates of the animal house. The animal was found to be dragging its body with bearing weight on the fore limbs. On clinical examination of the animal, it had weak pin prick reflexes in the right hind limb and absence of reflex in the left hind limb. Tail was flaccid. Urinary incontinence was observed. Rectal temperature and pulse rate were within the normal range.

The animal was confined to the house only. Two doses of 80mg Depo-Medrol injections (Methylprednisolone acetate, Pharmacia, Belgium) were given epidurally at weekly intervals. Physiotherapy was provided by infra red rays (infraphil, Peico Electronics \& Electricals Ltd., Calcutta, India) in a vertical manner from the lumbar region towards the foot daily for five minutes to both the hind legs. Daily massage of the hind quarters with Turpentine Liniment was done for a fortnight. To minimize the atrophy of thigh muscles, E-CARE Se (Health Line Pvt. Ltd., Bangalore) injections $10 \mathrm{ml} \mathrm{i/m}$ was given daily for five days. Oral supplementation with preparations having calcium and zinc was done till the recovery of the animals. After a week the animal was able to bear weight on the right leg. In a fortnight the animal was bearing the weight in both the hind legs. Physiotheraphy was discontinued after 15 days. Slight atrophy of the thigh muscles was observed at the end of the treatment (Image $2^{\mathrm{w}}$ ). However staggering persisted in the gait of the animal for 15 days. After two months the animal was able to walk normally. No reoccurrence of paraplegia was seen for next one year.

Paraplegia could be due to many reasons like subluxation, hind quarter injury etc. Diagnosis can be made by physical, neurological and imaging techniques. Grading of pelvic limb dysfunction can be done starting from grade 0 , i.e., paraplegia to grade 5, i.e., normal strength and coordination (Renegar, 1990). The lioness in this case was graded from 1-4. Slippery floors due to presence of water used during cleaning of the animal houses could have been one of the predisposing factors. Sudden exercise after long period of decreased physical activity like confined to cages could also be a predisposing factor. Epidural injection of long action steroids, physiotherapy and complete rest helped to recover from paraplegia in the present case.

\section{REFERENCES}

Oliver, J.E. (1987). Paresis or Paralysis, pp. 427-442. In: Small Animal Medical Diagnosis, Lorenz, M. and L.M. Cornelius (Eds.). J.B. Lippincott Company, Pennsylvania.

Reneger, W.R. (1990). Axial skeletal fractures. In: Canine Orthopedics $2^{\text {nd }}$ Ed. Whittick, W.G. (Ed.). Lea \& Febiger, Philadelphia, 311pp.

\section{ACKNOWLEDGEMENT}

Authors are thankful to Mr. K.B. Markandaiah, Executive Director \& Deputy Conservator of Forests, Bannerghatta Biological Park, Bangalore for giving permission to publish this paper.

"See Images 1 \& 2 in the web supplement at www.zoosprint.org 